\title{
Deadlock and Denial: Domestic Challenges and the Institutionalization Human Rights in ASEAN
}

\author{
${ }^{1}$ Universiteit Leiden, Leiden Insitute for Area Studies, Leiden, Netherlands, E-mail: irehadi@gmail.com
}

\begin{abstract}
:
In the last decade, ASEAN has made substantial steps towards adopting human rights, by creating the ASEAN Intergovernmental Commission on Human Rights (AICHR) in 2009 and adopting the ASEAN Human Rights Declaration in 2012. However, these developments do not lead to the establishment of an ASEAN Human Rights Mechanism. The article aims to investigate the deadlock in ASEAN by examining to what extent that relates to institutional challenges i. e. legal and political structures consist of existing norms, persistent discourses pertaining to human rights, at regional and national levels.
\end{abstract}

Keywords: ASEAN, human rights mechanism, AICHR

DOI: $10.1515 / g j-2018-0001$

\section{Introduction}

Human rights continue to be an exiting field of discussion in the Association of South East Asian Nations (ASEAN) politics. Several member states have officially declared their commitments to international human rights norms and integrated them into their domestic legal resources. Aside from Brunei, Malaysia, Myanmar and Singapore, the other six members of ASEAN are parties to both International Covenant on Civil and Political Rights and International Covenant on Economic, Social and Cultural Rights. Moreover, international human rights norms have also been integrated into national constitutions of several countries in the region. The Constitution of the Kingdom of Thailand of 2007 guarantees the rights, freedoms and equality of the people. Human rights have also established a prominent status in the domestic legal order of the Philippines, as one of the first countries that ratified both Covenants. In 2004, the Indonesian Constitution was amended to include prominent changes pertaining to human rights protection. In the last decade, furthermore, ASEAN makes substantial steps towards adopting human rights. Human rights are now embedded in the aims of ASEAN as provided in the ASEAN Charter. Member states created the ASEAN Intergovernmental Commission on Human Rights (AICHR) in 2009 that was charged with promoting human rights, and in 2012 released the ASEAN Human Rights Declaration (hereafter the Declaration) which for the first-time details what ASEAN means when it uses the words 'human rights'.

These developments have however received mixed reviews. Despite the international commitment and the integration of human rights norms into national constitutions, the state members of ASEAN remain reluctant to a pursue stronger agenda in realizing human rights protection at the regional level. Scholarly discussions on this topic have offered numerous criticisms on the role of AICHR and the substantive content of the Declaration in promoting and protecting human rights of the citizens of Southeast Asian countries. The article aims to investigate the deadlock in creating a single ASEAN human rights mechanism by examining to what extent that relates to institutional challenges i. e. legal and political structures consist of existing norms, persistent discourses pertaining to human rights, at regional and national levels.

The process of establishing a regional human rights mechanism in Southeast Asia cannot be separated from the domestic situation of each nation and across the region. The proliferation of human rights as well as the institutionalization of human rights norms in domestic political structures are considered as important factors that determine the effectivity of a regional mechanism. It is often argued that if a state achieves a good human rights record, then a strong regional human rights mechanism not only will be relatively unthreatening, but also provides more additional support for more national supports. ${ }^{1}$ The better human rights records in each state are, the more likely a regional human rights mechanism to be realized. ${ }^{2}$ Moreover, many times the national systems have proven insufficient especially if they are unable or unwilling to monitor, act and offer redress to individuals in case of violations. There is thus a need for regional arrangements to overcome or prevent lacunae and further enhance promotion and protection of human rights. ${ }^{3}$ It is often also claimed that regional human right mechanisms have proven to be more effective and useful in promoting and protecting human rights than 
the United Nations global human rights mechanism because they cannot only be complementary to the UN system but also operate in the regional context, reflecting regional particularities. ${ }^{4}$

In the context of Southeast Asia, analyzing the ASEAN human rights system vis-à-vis the various domestic structure entails several considerations, not only the different legal and political structures but also a common position taken by States towards human rights, usually known as the 'Asian values'. Although the debate on Asian values is not as contentious now as it was in the 1990s, it still implicates domestic and regional discourses and goals pertaining to human rights. Indeed, many factors affect the calculations of state actors as they consider whether to commit human rights instruments. As argued by Acharya in his seminal work on human rights in ASEAN; "the global prominence of a norm and the reputational power of transnational norm entrepreneurs are necessary but not sufficient conditions for successful norm diffusion". In other words, there are domestic conditions and specific local concerns that shape how human rights laws and norms are accepted or denied.

It is in this complexity that the article aims to discuss the normative and empirical realities that constitute the challenges faced by the process of institutionalizing human rights. Attention is placed to those realities in the major democracies that continue experiencing turbulences in Southeast Asia: Indonesia, the Philippines and Thailand. These three countries are regarded not only as the major players in the region. They are new democracies that push forward stronger human rights agenda. ${ }^{5}$ Specifically, after the collapse of the authoritarian New Order regime, Indonesia held its first free parliamentary elections for decades in 1999 and continues consolidating its newfound freedom. The Philippines also fits the category. While popular protests in 1986 ended the Marcos dictatorship and established a democratic system, Filipino politics has been characterized by instability. Thailand is also considered in this article for its particularly complex political history between the military and the government, while having a liberal constitution.

In examining the topic, the article is arranged as follow. The next section explains what the deadlock at the regional level is concerned by examining the evolutionary nature of the human rights discourses and practices in Southeast Asia. Thereafter, a comparative analysis on the protection of human rights in three countries Indonesia, the Philippines and Thailand will be made. The discussion section will cover an examination of the regional deadlock of establishing a human rights mechanism in relation to the specific domestic realities existing in the referred countries. Some concluding remarks are provided by the end of this article.

\section{The Deadlock: is there an ASEAN human rights mechanism?}

For more than four decades, human rights scholars have reproached ASEAN for not having a human rights system. Abundant references to the long history of the European system for protecting human rights, the growing significance of the Inter-American system, and the African system on Human and Peoples' Rights have thrown a spotlight on the gaping lacunae in Asia. Many expect a different situation when all Member States, also Brunei Darussalam, Cambodia, Laos, Myanmar, and Vietnam, decided to adopt a new agreement, the ASEAN Charter in 2007. The Charter asserts the promotion and protection of human rights in the region, however whether what is evolving in ASEAN - in terms of its declared human rights norms, their corresponding institutions and decision-making processes may constitute a "human rights mechanism" in its classical sense needs to be examined carefully.

Advocates to regional-level human rights mechanism argue that the special role such mechanism can play in the promotion and protection of rights. It may navigate places beyond the state but sufficiently local for them to be more accessible than the United Nations (UN) human rights mechanisms. It may offer a next resort for victims of rights infringements to whom there are either no available avenues for seeking domestic redress, or to whom the national justice system has neglected. Furthermore, they can reinforce the international human rights norms in its efforts to shape national policies, bringing about more human rights friendly practices, and, once these are implemented, can also help to prevent the process from ratcheting back. ${ }^{6}$ All of these are possible provided that there is a working infrastructure that supports the implementation of the agreed human rights norms. ${ }^{7}$ In this light, the following paragraphs discuss the adoption of human rights norms in ASEAN politics and the following institutional arrangements.

\subsection{The adoption human rights norms in ASEAN}

ASEAN member states often rely on the rising economic achievements or the "economics-first" argument ${ }^{8}$ and the collective and family values in negotiating human rights, especially with the Western members of international community. The underlying objection is that human rights, as formulated in international law and applied by States in international relations, are incompatible with the uniqueness of Asian societies and that human rights can only be enjoyed after a certain level of socio-economic development is reached. ${ }^{9}$ Societies 
in Southeast Asia have developed different perceptions based on different experiences regarding relations between man and society, and, therefore, a greater sensitivity is claimed towards 'the immense complexity of the issue of human rights due to the wide diversity in history, culture, value systems, geography and the phases of development among the nations of the world'. ${ }^{10}$ Nevertheless, the recent change in the ASEAN human rights negotiation happened for at least two factors. Firstly, the member countries have been attempting to deal efficiently with new challenges. Secondly, the process of democratization in prominent member countries have implicated how ASEAN deals with non-state actors.

Concerning the first, the outbreak of economic crisis 1997-1998 Asian financial crisis exposed the vulnerability of the Asian counterview on human rights, particularly pertaining to economic development. It provided a boost for the proponents of universal human rights. Many noted as a 'modest progress' towards the acceptance of human rights discourses and democracy, ${ }^{11}$ allowing an evaluation of the region's idea on sovereignty and economic welfare. For instance, in his opening speech for the 6th ASEAN Summit in 1998, President J.E. Estrada of the Philippines persuaded his colleagues to develop a more interventionist mechanism of regional cooperation by proposing regular consultations with academics, businesses and other stakeholders in the society. ${ }^{12}$ In a similar vein, the Thai former foreign minister, Surin Pitswuan, targeted the doctrine of non-interference by arguing for a policy of 'flexible engagement' that would allow ASEAN to address regional crises caused by domestic situations. ${ }^{13}$ Pitsuwan's idea is similar to that made by Malaysian Deputy Prime Minister, Anwar Ibrahim, on 'constructive engagement' made to articulate ASEAN involvement in the Cambodian internal political crisis. ${ }^{14}$ What follows was the reformulation of the organization's vision on economic development. Problems, such as malnutrition and poverty, which used to be considered as internal State issues, were recognized as regional issues. This transformation of political attitude was first officially documented in the ASEAN Vision 2020 of 1997,15 which is a declaration for a concerted effort to eradicate societal challenges, such as hunger, malnutrition, deprivation and poverty; a goal that will be achieved through strengthening ASEAN's institutions and mechanisms. ${ }^{16}$

Secondly, transitions to democracy in the largest and most populous Member State, Indonesia, which has intimated its interest in changing ASEAN practices, particularly pertaining to its engagement with non-state actors. Namely civil society organizations and human rights commission played active roles in pressing the State leaders into adopting a binding document that gives effect to the creation of an ASEAN human rights body. Initial consultations and dialogues held between the High-Level Task Force and the civil society organizations, as well as the national human rights commission in Indonesia, Malaysia, the Philippines and Thailand produced progressive outcomes. For example, the Action Programme declared in the 10th ASEAN Summit of 2004 mentions that the promotion of human rights should be carried out through enhancing networks between national human rights institutions ${ }^{17}$ and is considered as part of the goal to establish an ASEAN Security Community. ${ }^{18}$

Notably, the two factors mentioned above have worked in creating a conducive environment for the human rights promotion across the region, especially at the level of diplomacy. Member states no longer hesitated to engage in diplomacy regarding other's internal human rights situations. ASEAN, through an Inter-parliamentary Myanmar Caucus and a network of parliamentarians from Malaysia, Indonesia, the Philippines, Thailand and Cambodia, played a critical role in the international diplomacy regarding the human rights situation in Myanmar. Malaysia, through its Foreign Minister, Syed Hamid Albar, acted on behalf of ASEAN in order to gain some leverage over the internal reforms and the release of political prisoners, including Aung San Suu Kyii.

Thereafter human rights are not an off-limits anymore in ASEAN's formal agreements and documents. In fact, ASEAN Charter of 2007, entered into force 15 December 2008, officially asserts respect for human rights and fundamental freedoms, as well as the rejection of unconstitutional and undemocratic changes of government. The Charter serves as material basis for the ASEAN human rights Declaration, adopted in 2012. In more specific wording, the Declaration stipulates similar provisions embedded in international human rights treaties, both civil and political rights ${ }^{19}$ as well as economic, social and cultural rights. ${ }^{20}$ It contains a clear enunciation of the duties of ASEAN member-states to respect, promote and fulfil the human rights and freedoms. In addition to the first and second-generation rights typically promoted in international human rights instruments, the Declaration sets out third generation rights, building on provisions in the UN Declaration on the Right to Development (1986) and the right to peace. However, some expressions of reluctances remain. The Declaration counter-balances individual rights and freedoms with the duties of individuals to larger communities and to their institutional embodiment in the form of the state. Article 6 of the Declaration asserts: "The enjoyment of human rights and fundamental freedoms must be balanced with the performance of corresponding duties as every person has responsibilities to all other individuals, the community and the society where one lives." 21 Moreover, while the Declaration asserts the universality, indivisibility, interdependency and interrelatedness of all human rights and fundamental freedom, at the same it also stipulates the importance of recognizing the particularities and differences exist both at the regional and national level. Article 7 states that "the realization 
of human rights must be considered in the regional and national context bearing in mind different political, economic, legal, social, cultural, historical and religious backgrounds" ${ }^{22}$

\subsection{Institutional arrangements for human rights in ASEAN}

As mentioned, in order for a human rights mechanism to work there should be working institutional arrangement that supports the implementation of the agreed human rights norms. In this light, the legal basis for establishing a human rights mechanism can be found in Article 14 of the Charter which not only asserts that "in conformity with the purposes and principles of the relating to the promotion and protection of human rights and fundamental freedoms, ASEAN shall establish an ASEAN human rights body", but it also clarifies the position of human rights bodies within ASEAN main organs. ${ }^{23}$ Specifically, human rights are discussed within the agenda of ASEAN Political Security Community (APSC). This body has the mandate to 'promote political development in adherence to the principles of democracy, the rule of law and good governance, respect for and protection of human rights and fundamental freedoms as inscribed in the ASEAN Charter' ${ }^{24}$ The renewed structured on ASEAN main organs and its current human rights actors is illustrated below (Figure 1).

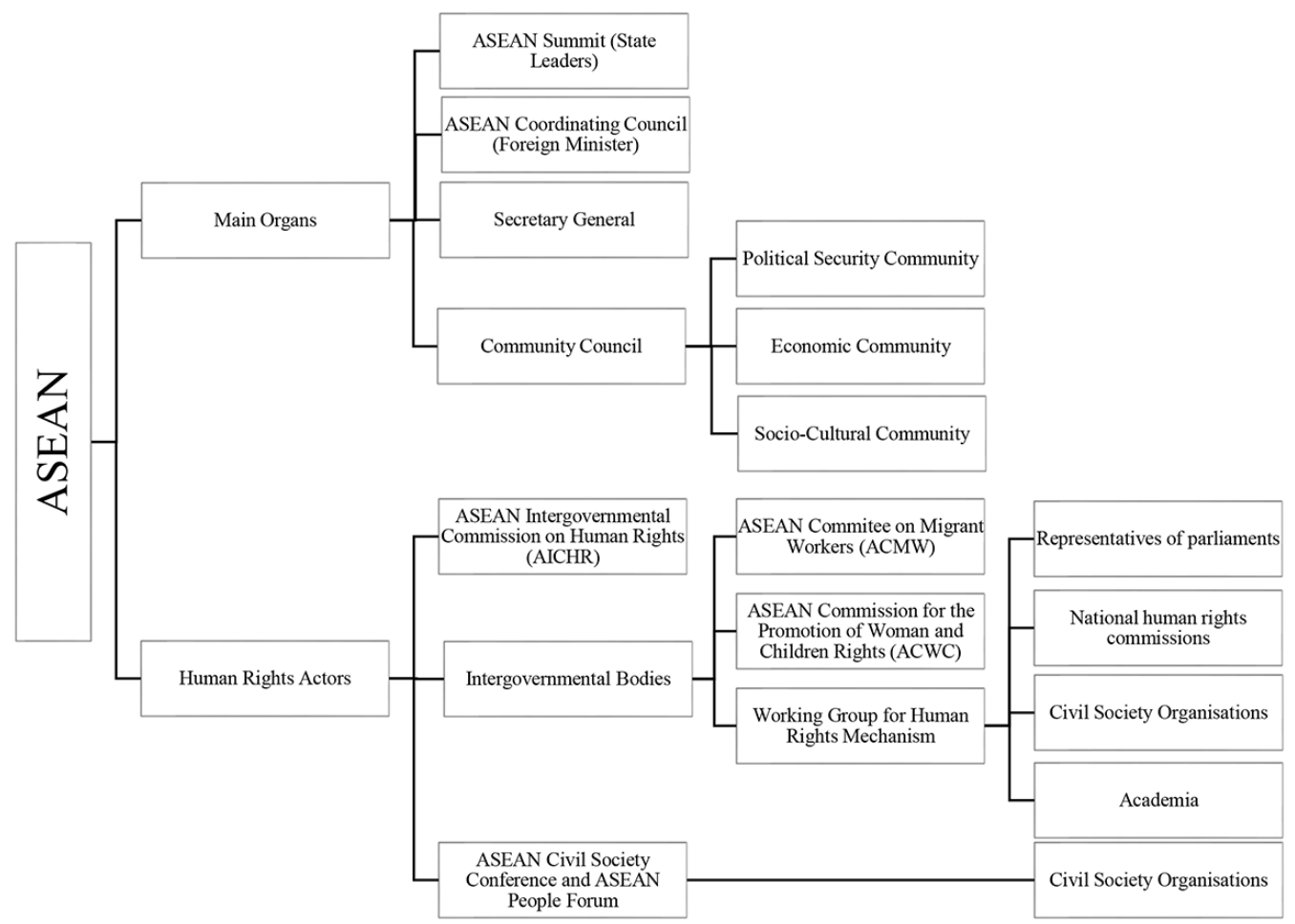

Figure 1: ASEAN main organs and human rights bodies ${ }^{25 .}$

What apparent in the structure is the two-models of governance, one is the inter-governmental model with regard to the main organs, the other is the governmental and non-governmental model concerning human rights. Responsible for the overall conduct of ASEAN the main organs consist of official representatives, which actually still represent the old state-to-state tradition of ASEAN. The dynamic is rather different in the context of human rights, where non-State actors can now officially contribute to the development and the progress of institutionalizing human rights in ASEAN. The structure shows a logical consequence of domestic political changes experienced in some of Southeast Asian democracies, Indonesia, Thailand and the Philippines, whose civil society organizations have been the driving forces behind the quest for a regional commitment to democracy and human rights. The ASEAN Civil Society Conference and the ASEAN Peoples Forum have been credited to make visible, for examples, both the violations of the human rights of sexuality and gender diverse people and the impacts of those violations on these people and their community. ${ }^{26}$

Within the structure, AICHR is arguably the most important human rights organ of ASEAN. As the first regional human rights commission in Southeast Asia, AICHR was established with the Cha-Am Hua Hin Declaration resulting from the 15th ASEAN Summit in 2009. The body is mandated to, inter alia, promote and protect human rights at the regional level by engaging in a dialogue with Member States, academia and civil society organizations, ${ }^{27}$ as well as, if required, other national, regional and international institutions concerned with the promotion of human rights. ${ }^{28}$ Another important task is 'to develop an ASEAN Human Rights declaration 
with a view to establishing a framework for human rights cooperation through various ASEAN conventions and other instruments dealing with human rights'. ${ }^{29}$ This mandate promises for a continuing efforts towards establishing a human rights mechanism in ASEAN.

AICHR consists of nominated representatives of each Member State who are answerable to States. Its existence is regulated based on the Terms of Reference (TOR). ${ }^{30}$ After a vigorous negotiation, the High-Level Panel, which drafted the TOR, designed AICHR to function as a political body and perform consultative tasks but, consequently, not having independent power. As many have commented, ${ }^{31}$ the apparent 'lack of teeth' is reflected in the 14 considerably weak functions of the AICHR. These functions that include developing strategies for human rights, enhancing public awareness of human rights, and providing advisory research related to human rights, focus predominantly on the promotion of human rights, and limits its role to an advisory body for the ASEAN Secretariat and member states, rather than giving the commission independent enforcement powers. AICHR does not receive individual communications or conduct investigations. Regarding decisionmaking, it shall be based on consultation and consensus in accordance with Article 20 of the ASEAN Charter, which stipulates that the ASEAN Summit may decide on how a specific decision can be made in case consensus cannot be achieved. This arrangement means that each State would be able to reject any criticism of its own human rights record by veto. ${ }^{32}$

Ultimately, a stronger regional promotion for human rights can exist when states determine that such instruments are in their interest and accept greater codification of human rights norms. This seems apparent in the case of ASEAN, nevertheless, despite an official endorsement to human rights norms is now found in a legally binding ASEAN Charter, the establishment of an ASEAN human rights mechanism proceeds cautiously. In addition to the recognition of the importance of the principle of non-interference in the Preamble, other provisions in the Charter may be potentially unfavorable. Articles 2(2)(b), (e), and (f $)^{33}$ respectively assert the principles of independence, sovereignty, and non-interference in internal affairs and respect for the right of every Member State to lead its national existence free from external interference, subversion and coercion. One could optimistically argue, however, that the Charter does not specifically subjugate human rights under these distinctive ASEAN principles. Moreover, Article 14 has made it possible to establish the AICHR as a political and consultative body responsible for the promotion of human rights in Southeast Asia.

\subsection{Is there an ASEAN human rights mechanism?}

The creation of the AICHR has clearly marked a transformation in the region's engagement with human rights. The region was famous for adversarial stances towards notions of-and politics around-human rights. Such stances might not be quite apparent in the light to the adoption of ASEAN Charter, ASEAN Human Rights Declaration and the establishment of AICHR. Yet, vagueness in terms of what ASEAN wants to achieve remains. As ASEAN decided against creating a formal human rights court and instead opted for an intergovernmental commission comprised of government-appointed members, ${ }^{34}$ what follows is positioning AICHR as a 'consultative body', ${ }^{35}$ with no independent power. The 14 listed functions of the AICHR required further clarification, such as 'develop strategies for the promotion and protection of human rights', ${ }^{36}$ 'enhance public awareness of human rights ... through education, research, and dissemination of information', ${ }^{37}$ and 'provide advisory services and technical assistance'. ${ }^{38}$

All of them rising practical questions not only about AICHR's power to navigate the complexity between regional and domestic politics of human rights, but also about whether expectations towards their active roles to implement the ASEAN Human Rights Declaration are realistic. In this regard, Langlois accounts the deadlock as an "institutional refusal"39 — which in this case are ASEAN's rejection to establish a strong human rights body and the failure of AICHR to draft an ASEAN Declaration of Human Rights that is satisfactorily able to be implemented according to the existing human rights standards. An observed and real outcome here is that the progress of institutionalizing of human rights within ASEAN has been placed under a normative and rhetorical banner, without an effective enforcement mechanism to protect the declared rights in the region.

To unpack this further, an examination to which factors affecting the calculations of state actors as they consider whether to institutionalize human rights norms is necessary. Domestic, regional, and international factors tend to vary, with constantly changing conditions that affect states' decisions to move forward to improve human rights protections, to resist such efforts, or to seek self-interested compromises. 


\section{Domestic legal and political challenges: human rights Denials in Indonesia, Thailand, and the Philippines}

As it is often argued, if a state achieves a good human rights record, then a strong regional human rights mechanism not only will be relatively unthreatening, but also provides more additional support for more national supports. ${ }^{40}$ The better human rights records in each state are, the more likely a human rights mechanism to be realized. What this entail is that domestic conditions could shape the calculations of state leaders as they weigh whether strong human rights mechanisms will benefit their states. However, not all factors in domestic levels contribute positively to the progress of institutionalization, they can also serve as counter legalization forces, offering disincentives for states to adopt human rights protection mechanisms in both domestic and regional politics. This section aims to discuss the existing legal frameworks for human rights in three Southeast Asian nations. Indonesia, Thailand and the Philippines can be classified as "newly established democracies" that face internal oppositions to the new democratic system. Being categorized as such, these countries should ideally support a robust regional human rights body, in order to secure the democratic gains made in their own countries. ${ }^{41}$ In the following paragraphs, it will be examined the constitutional basis for human rights protection in these countries and the issues faced in the implementation, in order to identify where they stand and to what extent these rights have legal standing in domestic courts.

\subsection{Indonesia}

The original version of the Indonesian Constitution, was formulated by the Preparatory Committee of Indonesia's Independence on 18 August 1945, one day after the Proclamation of Independence. ${ }^{42}$ After the dawn of the New Order Regime in 1998, there have been four amendments of the Indonesian Constitution.

Article 28 of the Fourth Amendment of the Indonesian Constitution expands the protection of human rights. This Article guarantees a number of universally accepted human rights, namely the right to freedom of assembly, ${ }^{43}$ the right to life, ${ }^{44}$ the right to establish a family, ${ }^{45}$ the right to personal development, ${ }^{46}$ the right to be treated equally before the law, ${ }^{47}$ the right to work and employment, ${ }^{48}$ the right to religion and freedom to express opinion, ${ }^{49}$ the right to information, ${ }^{50}$ freedom from torture and inhuman and degrading treatment, ${ }^{51}$ the right to a healthy environment, ${ }^{52}$ and the right to be free from discriminative treatment. ${ }^{53}$ The protection of freedom of religion is guaranteed under Article 29. Economic, social and cultural rights are assured in Articles 31 and 32, which respectively affirm the right to education and the right to cultural life. There are also two articles dedicated to regulating the national economy and social welfare in the fourth amendment of the Indonesian Constitution. ${ }^{54}$ Article 33 stipulates that development shall be organized in the common endeavor based upon the principles of the family system..$^{55}$ This means that all resources shall be used to the greatest benefit of the people ${ }^{56}$ while bearing in mind 'the principles of togetherness, efficiency with justice, continuity, environmental perspective, self-sufficiency, and keeping a balance in the progress and unity of the national economy. ${ }^{57}$ In addition to these basic rights, the Constitution also asserts the provisions on human obligations; by stipulating that:

in exercising his/her rights and freedoms, every person shall have the duty to accept the restrictions established by law for the sole purposes of guaranteeing the recognition and respect of the rights and freedoms of others and of satisfying just demands based upon considerations of morality, religious values, security and public order in a democratic society. ${ }^{58}$

From 1998 to date, many legal documents have been enacted to increase human rights protection and promotion, including the Law No. 39 of 1999 on Human Rights, the Law No. 26 of 2000 on Human Rights Court, the Law No. 23 of 2004 on the Elimination of Gender Violence, the Law No. 27 of 2004 on Truth and Reconciliation Commissions, the Law No. 21 of 2007 on Human Trafficking, Government Regulation No. 3 of 2002 on Compensation, Restitution and Rehabilitation against Gross Violations of Human Rights, and Government Regulation No. 56 of 2010 on the Elimination of Racial and Ethnic Discrimination. Indonesia is also a party to the CCPR, CESCR, CERD, CEDAW, CAT and CRC. The ratification of CAT, CCPR and CESCR was considered by international community as a big step forward for Indonesia in accepting human rights standards.

Within the overarching legal framework of human rights, domestic human rights institutions and other rights sectors have continued to move along different trajectories. ${ }^{59}$ The National commission of Human Rights is especially mandated to increase awareness of human rights, monitor and investigate human rights practice and provide advisory opinions and suggestions to the government, among others. The years of authoritarian were reported as the 'golden years' for the effectiveness of the Commission. Members of the Commission acquired extensive co-operation of state agencies - including the military and the police - which were all directly 
answerable to the President. ${ }^{60}$ However, the current criticism of the Commission is posed with regard to the inability to achieve executive and judicial outcomes. ${ }^{61}$ Their long ago completed pro justitia inquiries (in the cases of "Trisakti 1998, Semanggi 1998, and Semanggi 1999", "May Riot of 1998" as well as "Wasior 2001-2002 and Wamena 2003") have not been receiving any significant responses from the government and are not being followed up by the Commission. The Attorney General remains unresponsive to the result of their investigation or to execute formal investigations to follow up these cases. On the other hand, a long list of undecided cases on forced disappearance of human rights defenders and violations of citizens' right to vote in the 2009 election still awaits responses from the Commission.

Moreover, the fall of authoritarian regime has neither brought a completely different pattern of human rights advocacy nor uniformly affected promotions on different kinds of rights. The Indonesian submission to the Universal Periodic Review reveals several subjects concerning human rights that are considered 'important' the government. These are freedom of expression, freedom of religion, access to political participation, right to education, women rights, child rights, and migrant rights, as well as the protection against human trafficking. ${ }^{62}$ However, some areas of serious human rights abuse have remained quarantined because of their political sensitivity. The Indonesian government has been especially more reluctant to recognize right claims in conflict-prone zones. ${ }^{63}$ Indonesian authorities continue to restrict access by foreign journalists and rights monitors to Papua. The claims made based on indigenous rights in relations to natural resources management has been ignored. Similar is also experienced by victims claiming for truth and justice of 1965 gross human rights violations. ${ }^{64}$

The sudden change of power in Indonesia in May 1998 makes one forget that for more than three decades the Suharto regime had restricted the negotiation of human rights by considering them as subversive ideas and incompatible with the national ideology Pancasila. The preceding paragraphs shows despite the constitutional status of human rights there are still issues in the implementation. Forward-leaning ideas reflected in the human rights legal framework continue to clash with discourses, practices and policies being implemented to control borders and national stability. ${ }^{65}$ Political lobbying was argued as responsible for the creating deadlocks in bringing truth and justice to victims past human rights violations. ${ }^{66}$ Moreover, human rights are not yet instrumental in designing and assessing the process and outcomes of development and the management of natural resources. ${ }^{67}$ Against such a complexity, understanding the process of implementation of human rights in Indonesia demands an understanding of whether the failures of protecting right holders are actually resulting from the lack of commitment to enforce human rights, or the evolution of the State's role in adapting to new conditions or rules of the game for policymaking according to human rights standards.

\subsection{Thailand}

The original version of the Thai Constitution of 1949 was greatly influenced by the Universal Declaration of Human Rights, and replicated most of the provisions of the Universal Declarations. ${ }^{68}$ The new constitution that came into force in 1997 brought some changes with regards to human rights and civil liberties. The Constitution was amended in 2007 with some revisions concerning the election and the role of the executive. ${ }^{69}$ However, the 2007 Constitutions still retains its extensive protection for human rights. Not only it provides detailed protection towards fundamental rights and freedoms, but it also empowers courts and other state organs to directly invoke the provisions. Section 27 reads that 'The rights and liberties, recognized by this Constitution expressly, by implication or by decisions of the Constitutional Court, shall be protected and directly binding on the National Assembly, the Council of Ministers, the Courts, and other State organs in enacting, applying and interpreting laws'. ${ }^{70}$

The Constitution recognizes the principles of non-discriminatory, equality before the law, ${ }^{71}$ and human dignity. ${ }^{72}$ It guarantees the right to life, the right to fair trial, and the prohibition of cruel treatment and torture. ${ }^{73}$ The protection to the right to life is also provided in the Constitution and Penal Code. Furthermore, the 2007 Constitution also guarantees freedom of religion, 'provided that it is not contrary to his or her civic duties, public order or good morals' ${ }^{74}$ Freedom of speech is a constitutional right, which should especially be enacted for the purpose of 'maintaining the security of the State, safeguarding the rights, liberties, dignity reputation, family or privacy rights of the person, maintaining public or good morals or preventing the deterioration of the mind or health of the public' ${ }^{75}$ The Constitution guarantees freedom of association ${ }^{76}$ and freedom for assembly. ${ }^{77}$ Restriction to the latter is prohibited

except by virtue of law specifically enacted in the context of public assembly and to secure convenience for the people using the public place, or to maintain public peace and order during war or a state of emergency or when martial law has been declared. ${ }^{78}$ 
The right to fair trials is considered as a 'basic right', which is regulated the details in Section 40 of the Constitution. The section guarantees first of all 'the right to access to the process of justice that is easy, expedient, quick, available to all', ${ }^{\prime 9}$ and secondly

the right to an open trial, right to be informed of the facts, and to verify the documents adequately, right to present facts, refute, and produce witness and evidence, right to protest or refuse a judge or judges or examiners, right to be considered by judges or examiners in full quorum, and right to be explained about judgment or order. ${ }^{80}$

A similarly wide range of protection is also found with regard to socio-economic rights. The Constitution asserts the right to work - which includes the right to equal pay for work and to safe work environment. ${ }^{81}$ The right to education ${ }^{82}$ is specified as the right to receive education for the duration of not less than twelve years and to enjoy academic freedom. An equal right to health service is guaranteed in five sections of the Constitution, ${ }^{83}$ and they cover comprehensive aspect of public health. Collective rights guaranteed include the right to information, ${ }^{84}$ the right of traditional communities to conserve and restore their customs ${ }^{85}$ the right to self-determination, ${ }^{86}$ and the right to environment. ${ }^{87}$ The Constitution also contains several parts of policy directive, including a policy directive on religion, social, public health, education and culture. ${ }^{88}$ In addition to rights protected, the Constitution also acknowledges the duty of each citizens. Section 70 asserts that 'every person has a duty to protect and uphold the nation, the religion, the King, and the democratic regime with the King as the Head of the State'.

Hitherto, various human rights agencies have been established to monitor the government's compliance to human rights. These agencies are the Parliamentary Committee on Justice and Human Rights, the National Human Rights Commissions, the Department for the Protection for Rights and Liberties under the Ministry of Justice, the National Reconciliation Commission and the National Child Protection Committee. ${ }^{89}$ In comparison with other countries in the region, Thailand is also a more active participant in international human rights community. The country has ratified CAT, CEDAW, CRC (and its two optional protocols), CERD, CRPD, CESCR and CCPR (and its first optional protocol) long before other countries in Southeast Asia. Thailand has accepted the individual complaint mechanism of CEDAW and has signed, but not yet ratified the Rome Statute of the ICC. The OHCHR has also a Regional Representative for the Asia Pacific Region based in Bangkok.

These exemplary legal provisions and Thai's commitment to human rights in international community however do not directly affect the ways in which rights are being protected in domestic realities. Political instability is one of the main reasons. Since gaining independence, the military has successfully executed regular coups d'état that replace elected governments have gained legitimacy. The shift into overt authoritarianism in the last decade, under both elected and coup-appointed government has led to observers' view towards the country's performance of human rights. The political chaos from the coup has been about fundamental questions of order - who gets the rules of the game - and in part, about the place of rights. ${ }^{90}$ Yet in case of Thailand, this does not implies significant differences with regard to the types of human rights violations and how rights are being protected in the country's legal framework.

In coming to power, for example, Thaksin Shinawatra and his Thai Rak Thai inherited a public culture of impunity the phu yai, the 'big people'. His regime (2001-2006) presided over gross violations of human rights, including over a thousand deaths in the war of drugs and the Tak Bak killings of 85 Muslim unarmed protestors. Some cases concerning freedom of assembly have come to the attention of the National Human Rights Commission, for example, human rights demonstrators against the Thai-Malaysia gas pipeline, who has been intimidated by the police and those detained were denied access to their lawyers. However, the authority imposed a legal-political tactic to 'preempt' the Commission from exercising its powers to protect human rights defenders. By bringing the case to court, the authority was able to reinterpret the law concerning the powers of the Commission. This strategy prevented the Commission to further investigate cases since the authorities have already submitted them to a court of law.

Thaksin's period has been marked by a serious problem concerning rights to fair trial, freedom of religion, freedom of speech and forced disappearances. ${ }^{91}$ Analogous concerns are also raised by the Human Rights Watch in their UPR report of 2015. Censorship and restrictions on free expression, association and peaceful assembly are implemented after the latest military coup of 2014. Since the coup, 300 politicians, activists, journalists, and people are accused of supporting the deposed government, disrespecting the monarchy, or being involved in anti-coup protests and activities. ${ }^{92}$ Additionally, extrajudicial killings, enforced disappearances, arbitrary detentions, and torture have occurred regularly as part of the government's counterinsurgency campaign and in reprisals for insurgent attacks on the ethnic Thai Buddhist population and security personnel in the Southern part of the country. ${ }^{93}$

Oddly, many of the extensive rights contained in the 1997 'people's constitution', abrogated after the 2006 coup, reappeared in the current and military-back 2007 Constitution. Some scholars argue on the ritualistic status of these provisions, as 'independent organization' such as the National Human Rights Commission remains intact in the 2007 Constitution, although stronger control over them granted to the judiciary and the senate. ${ }^{94}$ 
Thailand, in sum, has still a strong domestic legal framework on human rights protection within the Southeast Asian region.

\subsection{The Philippines}

Compared to other societies in Southeast Asia, the Philippines has had more contact with the notion of human rights..$^{95}$ Its 1896 Revolution, the Asia's first nationalist, anti-colonial struggles, has established the foundation for human rights norms. A home-grown constitution was called 'the Political Constitution of the Republic' written in terms inspired by the French Revolution and it contained a separate title 'The Filipinos and their National and Individual Rights'. With the Marcos regime as an exception, people have enjoyed full voting rights since 1947. Fundamental rights have been an integral part of the Philippine Constitutions under laws adopted in 1898, 1935, 1973, 1986 and 1987. The 1987 Constitution marked the Philippines as the first Asian country to abolish the death penalty. Provisions provided in the Constitution guarantee respect for the dignity and the protection of human rights. Article III enumerates in twenty-one sections the 'Bill of Rights'.

The Article III recognizes the connection between the right to life, the right to fair trial and the right to privacy. ${ }^{96}$ The right to fair trial also includes the right to counsel, ${ }^{97}$ the right to speedy trial, ${ }^{98}$ and free access to the courts and quasi-judicial bodies. ${ }^{99}$ The protection of freedom of assembly and freedom of expression goes as far as 'no law shall be passed' to abridge them. ${ }^{100}$ The same goes with regard to the freedom of religion and the free exercise and enjoyment of religious profession and worships. ${ }^{101}$ A stronger provision in this regard is also provided in the Constitution, which asserts that 'no person shall be detained solely by reason of his political beliefs and aspirations' ${ }^{102}$ Prohibition of torture covers violence, force, threat, intimidation or any other means, including secret detention places, solitary and incommunicado. ${ }^{103}$

Article II, which covers the Section of Declaration of Principles and State Policies Principles, provides the protection of human dignity, ${ }^{104}$ the right to self-determination, ${ }^{105}$ and socio-economic rights. The latter covers the right to health, ${ }^{106}$ the right to environment, ${ }^{107}$ and the right to education. ${ }^{108}$ The rights of indigenous cultural communities are guaranteed 'within the framework of national unity and development' ${ }^{109}$ In addition to the Constitution, economic and social rights are provided for by various legal documents, including the Civil Code, the Labour Code, and the Family Code.

Observers often say that the 'Asian values' debate and the challenge to the universality of human rights do not resonate in Philippine human rights discourses. After the downfall of Marcos, traditional civil rights insulating the individual from state well powers. The Aquino regime also establishes the National Ombudsman and the Commission on Human Rights. These independent institutions are Aquino's attempt to 'de-ideologize' human rights, to drain it from the open-ended ideological contestation that were prevalent during the Marcos era. ${ }^{110}$ In the context of international human rights law, the Philippines is party to all major international human rights treaties, CAT, CCPR (and its first optional protocol), CEDAW (and its optional protocol), CERD, CESCR, CMW, CRPD, CRC (and its two optional protocols). As asserted in Article II of the 1987 Constitution, the Philippines "adopts the generally-accepted principles of international law as part of the law of the land". 111 Provisions of these human rights instruments can be invoked before and directly enforced by the courts, other tribunals or administrative. This characteristic is of special quality compared to other human rights systems in other countries in the region.

However, there are remaining challenges. Supreme Court has itself confined the term 'human rights' to civil and political rights and to exclude economic, social and cultural rights. ${ }^{112}$ The court examined the drafting history of the Constitution and found that the intent of the framers owing to the recent experience of abuses under Marcos was to create a Commission on Human Rights to protect traditional civil and political rights. The drafters were concerned that an emphasis to socio-economic rights might allow another authorities regime to use the classic trade-off arguments to justify curtailing civil and political rights in exchange for economic progress. ${ }^{113}$ Because of this limitations, it is often mentioned that in the Philippines, economics and politics have usually gone hand in hand and reinforce each other, which counters the argument often made by some other governments in Southeast Asia region. ${ }^{114}$ On the other hand, the post-Marcos governments are observed to be unresponsive to the extreme poverty and the huge gap between rich and poor. ${ }^{115}$

Despite the clear procedural aspect of the enforcement of human rights in the court of law, ambiguities are still found in some cases. The cases of church and state separation throws a light on the ways the Court attempt to protect freedom of religion. The court is observed to have not consistently applied the doctrine. In Gerona the court showed intolerance for minority religions, for example. ${ }^{116}$

Moreover, there has also been the resumption of human rights violations in the past decades. As indicated by international human rights NGOs, the patterns of the disappearances of leftist activist, journalists outspoken clergy, anti-mining activists, and agricultural reform activists show a structural intimidations, ${ }^{117}$ and reflect 'a state of total denial'. ${ }^{118}$ To date, violence against women, abuses of children, discrimination against Muslim, and extra judicial killing still persist. ${ }^{119}$ It has been reported that the Philippine military continues to be implicated 
in apparently politically-motivated extrajudicial killings in the Southern part of the country. These deliberate unlawful killings by state security forces persist in part because of the failure to conduct impartial investigations, particularly when evidence points to military involvement. ${ }^{120}$ Moreover, under Duterte's administration, authoritarianism is making a comeback, as he has threatened to abolish the constitutionally mandated Commission on Human Rights for criticizing his violent drug crackdown and has warned the Ombudsmen not to investigate police or military involvement without seeking his permission first. ${ }^{121}$

The Philippines Constitution has codified, bureaucratized and proceduralized human rights so that the law is easily used. The historical experience under Marcos dictatorship has brought cautions against loosing legal restrains on governmental power. Exceptional legal frameworks on papers do imply that the government, for the most part, respects the human rights of its citizens. Some argue how the human rights situation in the Philippines reflect a formalistic conception of human rights. ${ }^{122}$ Records are however still far from being perfect as the implementation and the enforcement are not always effective. ${ }^{123}$

\section{Discussion: a regional deadlock amidst domestic challenges}

The previous sections reveal some commonalities with regard to what extent human rights norms are accepted and denied Indonesia, Thailand and the Philippines. The Constitutions of these three countries assert wide-ranging human rights provisions that correspond to the universal human rights adopted in international treaties and declarations. The Constitutions not only guarantee civil and political rights, but also social, economic and cultural rights as well as some of the collective rights. Additionally, in all of the countries, there is a national human rights institution with relative independency and mandates to monitor the performance of human rights implementation.

Examining the historical and political background and context against which these stands on human rights are taken by each country, there are some particularities. In Indonesia, human rights norms and values were accepted in the country's legal system following the fall of Suharto's regime. This background alone shapes the realities of enforcement. The legal framework to promote human rights was passed for the certain reasons. One of which is because of international pressure, NGO pressure, or even for the purpose of holding onto power. ${ }^{124}$ The Human Rights No.39 of 1999 for example was drafted without making a good feasibility study of the supporting infrastructure for effective implementation, corresponding to its leniency of enforcement agencies. This abrupt introduction of a substantive law on human rights poses some problems at the enforcement stage as it involves transforming the political and legal culture of the politicians and the general public. With regard to international human rights treaties, their implementation is problematic because they are ratified but they have not been translated into domestic obligations. Consequently, domestic courts remain reluctant to apply the human rights norms ratified by Indonesia in their decisions and adverse national legislations and policies continue to be established.

In comparison with other countries in the region, Thai's Constitution is often considered consummate in the extent of which it provides a legal framework for economic, social and cultural rights, civil and political rights, as well as collective rights. Ironically, Thailand suffers from series of military dictatorships and weak fragmentary civilian coalition government, ${ }^{125}$ and this context influences the implementation of human rights. Episodes of regime changes in Thailand highlight there is a lack of fundamental agreement on political order among competing elite networks. In other words, there is no 'contingent consent' ${ }^{\prime 26}$ among Thai elites for a set of rules of the game resides in agreement on boundaries. Despite such transgressed boundaries, ${ }^{127}$ however, there is a fundamental and institutional basis for instigating regime changes. In fact, law and the law-making are constitutive part of regime changes and its political legitimation. ${ }^{128}$ As each political regime employ this strategy to gain and maintain their power, the promotion and protection of human rights also depends on the priorities of the authorities. The promotion of human rights for example had benefited from the current administration on some fronts, especially in its attempts to eradicate poverty, but a conflict of interests continues hampering the protection of rights.

As to the Philippines, this country has a longer experience with the protection of fundamental rights - the legal foundation for fundamental rights was established in 1896. Owing to this historical context, the rightsbased discourse pervades the public debate in the Philippines. Recent history also animates the ways human rights norms and discourses are perceived today. The rejection of dictatorship as experienced under Marcos and of the violations of human dignity that ensued. An example is the stern separation between civil and political rights and economic, social and cultural rights, a stand taken to discard Marcos' trade-off arguments between the two set of rights. Marcos's dictatorship also warns against loosing legal restraints of governmental power. ${ }^{129}$ Yet, this has consequence the strong emphasis on procedural aspect of realizing rights. Human rights are reduced to fixed rules to be enforced mechanically by non-political bodies owing their loyalty not to any 
political faction, but to an abstract constitution or constitutional ideals. ${ }^{130}$ In result, it has been problematic to encourage an open-ended ideological contestation aiming to promote the use of human rights and to challenge government's denial to the continuing human rights violations.

From these dissimilarities pertaining to the countries' historical and political context of human rights, one can draw several parallel characteristics concerning the registration and production of human rights. First, human rights norms were incorporated and/or revised in the Constitution at the same time when regimes in these countries were changing. Second, such a context contributes to ways human rights are perceived, particularly by political elites. The irony is that during political changes establishing non-friendly human rights mechanisms would not be something that the 'new' elites effectively aspire, but it would be naïve to suggest that human rights are accepted with uncontested intentions. In result, thirdly, the promotion and protection of the rights in Indonesia, Thailand and the Philippines depends on the reading and the writing of rights by the regimes in power. There is a myriad history of power and resistance that contributes to the stipulation and the interpretation of right in the Constitutions and in practices. The problem of pending cases on past human rights violations in three countries is an example in this regard.

Additionally, there is also the production of politics of human rights, both at the national level and at the regional level. At the national level, writing human rights norms and standards into a code of obligatoriness constructs a whole structure of constraints. A closer look to the role of national human rights institutes, which exists in each country, might show the extent of authority they have to interpret and monitor the realization of rights. The dynamics regarding their founding instruments, social and political conditions affecting their establishment, their mediation role and the provisions for the selection of the commission members of the four national human rights commissions illustrate why many national governments are wary of the human rights agenda. ${ }^{131}$ Weak legal foundations for constituting the human rights institutions in Indonesia, which stem from presidential decrees, parliamentary decrees and organic laws, affect their capacity to carry out effective human rights investigations and, at the same time, reflect the problem of political will. ${ }^{132}$ Nevertheless, stronger constitutional foundations could also not explain the lagging commitment to human rights as seen in the Philippines and Thailand. Observably, each nation has come to a variety, although remain comparable, of a balance to this regard. It needs to be further investigated, however, whether this balance concerns protecting right holders from the abuse of to be power as much as legitimating the operations of that very power.

At the regional level, the writing and reading human rights norms and standards in the ASEAN Human Rights Declaration reveals a production of regional politics as well. Yet, rather than contestations among nations concerning human rights standards and norms, what is observed is a common stand taken as to how and when human rights are accepted as regional standards. Despite the changing political economic environment in the region that transforms the narratives concerning ASEAN's positions towards human rights, there are values and practices that are maintained. An emphasis to decision making by consensus and non-interference in the internal affairs cannot facilitate the establishment of cooperative approaches and mechanisms having the potential to reach deep into member-States' sovereignty. In result, members maintain sweeping reservations towards a stronger human rights system in the region.

Nevertheless, such complexities both at national and regional levels does not imply a bleak future for human rights in ASEAN. Member countries continue to employ human rights rhetoric to address the regional peace and stability. Besides the success of relentless diplomatic negotiations conducted with the authoritarian regimes in Cambodia and Myanmar, ASEAN recently indicates towards assuming a prominent role to resolve the human rights situation in North Korea. In 2016, Marzuki Darusman, the UN special rapporteur on the human rights situation in North Korea suggested looking at new ways of addressing. ASEAN in his view could play role as a common regional platform for shared experiences might prove a useful entry point for dialogue. ASEAN countries have experience in discussing their human rights situation to international fora — such as Indonesia, the Philippines and Thailand. ASEAN, it is argued, would be of a suitable actor to engage with North Korea using the non-confrontational approach. ${ }^{133}$

Concerning the deadlock, a note can be made that in negotiating for a single human rights mechanism in ASEAN signifies the production of politics at the regional level that selectively observes human rights as tools to maintaining ASEAN collectiveness, amongst its members and also towards the international community, as domestic political turbulences continue to exist and challenges human rights bodies in many member countries. Moreover, historical as well as legal-political realities at observe human rights as obstacles for maintaining control and stability and this view continues creating obstacles for stronger enforcement in the national level. In result, human rights are not so much legal and political standards to impose constraints in the state and people relationship, which at the regional politics it means that they become a powerful diplomatic rhetoric to consolidate a common position taken by ASEAN, towards other states in Asia and international community, especially in times when regional peace and stability is at stake. 


\section{Concluding remarks}

In this article it has been discussed persistent politics to limitedly implement human rights in ASEAN. The changes that occurred following the Asian crisis in 1998 have opened a beginning for contesting differences regarding human rights. Official statements and documents were adopted to revise and reassert the united position that Member States had towards economic development, national sovereignty and the non-selectivity of human rights. Member states, especially Indonesia, Thailand and the Philippines, have incorporated human rights norms into their legal systems. There are different domestic trajectories with their associated various interests to include human rights norms in national constitutions and to establish national human rights institutions. In the light of these developments, one might assume that they could facilitate the establishment of a strong human rights mechanism to promote and protect human rights across the region. But, the ways human rights are declared and to what extent they can be enforced show that what seems to be positive changes at regional and national levels have observably little contribution in transforming the politics at the regional level, especially concerning the establishment of a single human rights mechanism.

Nevertheless, as argued in this article, the deadlock does not imply that there is no single position towards human rights taken by ASEAN. In fact, the adoption of the ASEAN Human Rights Declaration reveals a balancing act between rights and duties as well as between freedoms and collective harmony. This suggests a common acceptance to the ontological aspect of human rights. Yet as it has been explained before there are also conditions regarding how and when human rights are invoked. In this regard, the issue is not only about to what extent does the legal and political context feed into the efforts of establishing a single human rights mechanism, but about the selective human rights politics produced by ASEAN as a collective entity.

\section{Notes}

1 Donnelly, J. Universal human rights in theory and practice. (Ithaca: Cornell University Press, 2013).

2 Phan, Hao Duy. A selective approach to establishing a human rights mechanism in South East Asia: The case for a Southeast Asian court of human rights. (Washington DC: American University, 2009).

3 Muntarbhorn, V. 'Human Rights Monitoring in the Asia-Pacific Region' in Gudmundur Alfredsson (et. al) (eds.) International Human Rights Monitoring Mechanisms: Essays in Honour of Jakob Th. Möller (2nd ed.) (Martinus Nijhoff Publishers 2009): 641.

4 Weston, L. et al, 'Regional Human Rights Regimes: A Comparison and Appraisal' Vanderbilt Journal of Transnational Law 20, No 4 (1987): 589-590.

5 Munro, J. 'Why states create international human rights mechanisms: The ASEAN Intergovernmental Commission on Human Rights and democratic lock-in theory. Asia-Pacific Journal on Human Rights \& Law 10(2009): 1.

6 Croydon, S. 'Towards a regional human rights mechanism in the Asia Pacific?: Exploring the potential of the Asia Pacific Forum. The Pacific Review (2014): 290.

I 7 See: Jalal, I. 'Why do we need a Pacific regional human rights commission?', Victoria University of Wellington Law Review 40 (2009-2010): 117-94.; Mugwanya, G. 'Realizing universal human rights norms through regional human rights mechanisms: reinvigorating the African system', Indiana International \& Comparative Law Review 10(1999-2000): 35-50.; Okafor, O. The African Human Rights System, Activist Forces and International Institutions (Cambridge: Cambridge University Press. 2007); Shaw, C. 'The evolution of regional human rights mechanisms: a focus on Africa', Journal of Human Rights 6(2007): 209-32.

8 Ignatieff, M., Human Rights as Politics and Idolatry (New Jersey: Princeton Univ. Press 2001): 62.

9 Thio, L., 'Implementing Human Rights in ASEAN Countries: Promises to keep miles to go before I sleep'. Yale Human Rights and Development Law Journal 2, No.1 (1999): 12-25.

10 Alatas, A. A Voice for Just Peace: A Collection of Speeches by Ali Alatas. (Singapore: ISEAS, 2001): 474. As a defense the foreign minister of Singapore, Wang Kang Seng, addressed the World Conference on Human Rights in 1993 also said: We make no apology for doing what we believe is correct rather than what our critics advise. Singaporeans are responsible for Singaporean future. We justify ourselves to our people, not by abstract theories or the approbation of foreigners, but more by a rigorous test of practical success. See: ChunYing, X. 'Can a Pluralist World Have a Unified View on Human Rights?', in P. Baehr et. al Human Rights: Chinese and Dutch Perspectives. (The Haque: Kluwer Internasional, 1996):42.

11 Mohammad, M.,'Towards a Human Rights Regime in Southeast Asia: Charting the Course of State Commitment'. Contemporary Southeast Asia 24, No. 2 (2002): 246; Ramcharan, R., 'ASEAN's Human Rights Commission: Policy Considerations for Enhancing its Capacity to Protect Human Rights'. UCL Human Rights Review 3 (2010): 203; Manea, M. G. “How and why interaction matters: ASEAN's regional identity and human rights." Cooperation and Conflict 44, No. 1 (2009): 39.

12 Opening Remarks by H.E. Joseph Ejercito Estrada, President of the Philippines, Sixth ASEAN Summit, 1998, available at www.aseansec.org/13025.htm.

13 Manea, M. G. op. cit., p. 39.

14 Thio, L., op. cit., p. 44.

15 ASEAN Vision 2020, available atwww.aseansec.org/1814.htm.

16 Community of Caring Societies, para. 3.

17 Regarding human rights promotion, in addition, the Vientiane Actions Programme also specifies the following subjects: completion of a stock-taking of existing human rights mechanisms and equivalent bodies, including sectorial bodies promoting the rights of women and children; formulation and adoption of MOU to establish network among existing human rights mechanisms; formulation of work programme of the network; promote education and public awareness on human rights; establish a network of cooperation among existing human rights mechanisms; elaboration of an ASEAN instrument on the protection and promotion of the rights of migrant workers; establishment of an ASEAN commission on the promotion and protection of the rights of women and children.

18 Vientianne Action Programme 2004-2010, p. 6. Available at:www.aseansec.org/VAP-10th\%20ASEAN\%20Summit.pdf. 
19 Articles 10-25, ASEAN Human Rights Declaration

20 Articles 26-34, ASEAN Human Rights Declaration

21 Article 6, ASEAN Human Rights Declaration

22 Article 7, ASEAN Human Rights Declaration

23 The highest organ and the supreme policy-making body within the organization is the ASEAN Summit, comprised of the heads of State or government of the Member States. The Coordinating Council is a body consisted of foreign ministers, which coordinates the implementation of agreements and decisions of the ASEAN Summit. Practical organizational implementation as to related duties and responsibilities is carried out by the Secretary General. The Community Council is responsible for ensuring that the relevant decisions and agreements are related to the ASEAN visions 2015, which aim at creating community for political security, economic, and socio-cultural goals.

24 ASEAN. ASEAN Political Security Community Blueprint (2009). Available at: www.aseansec.org/22337.pdf.

25 Hadiprayitno, I. “The Institutionalisation of Human Rights in ASEAN'. In. A. Buyse et al (eds). Defending Human Rights: Tools for Social Justice (Antwerp: Intersentia, 2012): 49-68.

26 Langlois, A. Human Rights, “Orientation," and ASEAN. Journal of Human Rights 13, No. 3 (2014): 310-311.

27 ASEAN, Terms of Reference AICHR (2009), para. 4.8. Available at:www.asean.org/DOC-TOR-AHRB.pdf.

28 Ibid, para. 4.9.

$29 \mathrm{Ibid}$, para. 4.2.

30 Munro, J., 'The relationship between the origins and regime design of the ASEAN Intergovernmental Commission on Human Rights (AICHR)' The International Journal of Human Rights 15, No. 8 (2011): 1189.

31 Durbach, A. et al, “A tongue but no teeth?': The emergence of a regional human rights mechanism in the Asia Pacific region', Sydney Law Review 31 (2009): 211-238.

32 Ginbar, Y., 'Human Rights in ASEAN: Setting Sail or Treading Water?' Human Rights Law Review10, No. 3 (2010): 514.

33 Article 2 of the ASEAN Charter stipulates that principles adhered by ASEAN and its Member States. These include: shared commitment and collective responsibility in enhancing regional peace, security and prosperity (Article 2(2b)); non-interference in the internal affairs of ASEAN Member States (Article 2e); and respect for the right of every Member State to lead its national existence free from external interference, subversion and coercion (Article $2 \mathrm{f}$ ).

34 Munro, J., 'The relationship between the origins and regime design of the ASEAN Intergovernmental Commission on Human Rights (AICHR)' The International Journal of Human Rights 15, No. 8 (2011): 1189

35 Terms of Reference of the ASEAN Intergovernmental Commission on Human Rights, adoptedby the 42nd ASEAN Ministerial Meeting, 20 July 2009, http:/ / www.aseansec.org/Doc-TORAICHR.pdf (accessed 9 January 2018), para. 3.

36 Terms of Reference of the ASEAN Intergovernmental Commission on Human Rights, para. 4.1.

$37 \mathrm{Ibid}$., para. 4.3

$38 \mathrm{Ibid} .$, para. 4.7.

39 Langlois, A. op. cit., p. 316

40 Donnelly, J. op. cit., p. 152

41 Munro, J. 'Why states create international human rights mechanisms: The ASEAN Intergovernmental Commission on Human Rights and democratic lock-in theory. Asia-Pacific Journal on Human Rights \& Law 10 (2009): 10, 12

42 The original version offered protection of civil and political rights in Articles 27, 28, 29, providing entitlement to equal status, freedom of association and assembly, and freedom to religion, whereas protection of economic, social, and cultural rights was guaranteed in Articles $31,32,33$, and 34 . Notably, the original version was rather limited with simple provisions on human rights and therefore they were open to multiple interpretations.

43 Article 28, the Indonesian Constitution, Fourth Amendment.

44 Article $28 \mathrm{~A}$, the Indonesian Constitution, Fourth Amendment.

45 Article 28 B, the Indonesian Constitution, Fourth Amendment.

46 Article $28 \mathrm{C}$, the Indonesian Constitution, Fourth Amendment.

47 Article $28 \mathrm{D}(1)$, the Indonesian Constitution, Fourth Amendment.

48 Article $28 \mathrm{D}$ (2); the right to work is also guaranteed in article 27 (2), the Indonesian Constitution, Fourth Amendment.

49 Article $28 \mathrm{E}$, the Indonesian Constitution, Fourth Amendment.

50 Article 28 F, the Indonesian Constitution, Fourth Amendment.

51 Article 28 G (2), the Indonesian Constitution, Fourth Amendment.

52 Article $28 \mathrm{H}(1)$, the Indonesian Constitution, Fourth Amendment.

53 Article 28 I (2), the Indonesian Constitution, Fourth Amendment.

54 See articles 33 and 34, the Indonesian Constitution, Fourth Amendment.

55 Article 33 (1), the Indonesian Constitution, Fourth Amendment.

56 Article 33 (2), the Indonesian Constitution, Fourth Amendment.

57 Article 33 (3), the Indonesian Constitution, Fourth Amendment.

58 Article $28 \mathrm{~J}$ (2), the Indonesian Constitution, Fourth Amendment.

59 Ford, Michael, 'International Networks and Human Rights in Indonesia', in Thomas W.D. Davis and Brian Galligan (eds). Human Rights in Asia. (Glos, UK: Edward Elgar, 2011): 46.

60 Mohammad, M.,'Towards a Human Rights Regime in Southeast Asia: Charting the Course of State Commitment'. Contemporary Southeast Asia 24, No. 2 (2002): 239.

61 The Indonesian Human Rights Monitor (IMPARSIAL), 'The Indonesian National Human Rights Commission's Performance in 2009 to Early 2010'. 2010 ANNI Report on the Performance and Establishment of National Human Rights Institutions in Asia. (Thailand: Forum Asia Pub. 2010): 81-90

62 Human Rights Council, National report submitted in accordance with paragraph 5 of the annex to Human Rights Council resolution 16/21 - Indonesia, A/HRC/WG.6/13/IDN/1, 7 March (2012): 15-20.

63 Hadiprayitno, I. 'Defensive Enforcement: Human Rights in Indonesia'. Human Rights Review 11 (2010).

64 Wahyuningroem, S.L., 'Seducing for Truth and Justice: Civil Society Initiatives for the 1965 Mass Violence in Indonesia', Journal of Current Southeast Asian Affairs 32. No. 3 (2013): 137.

65 Juwana, H. 'Human Rights in Indonesia', in Randall Peerenboom et. al. (eds). Human Rights in Asia: A Comparative Case Study of Twelve Legal Jurisdictions, France and the USA. (New York: Routledge, 2006): 366.

66 Ibid.

67 Hadiprayitno, I., 'Behind Transformation: The Right to Food, Agricultural Modernisation and Indigenous Peoples in Papua, Indonesia'. Human Rights Review 16 (2015): 123-141. 
68 Muntabhorn, V. ' Human Rights in Thailand', in Randall Peerenboom et. al. (eds). Human Rights in Asia: A Comparative Case Study of Twelve Legal Jurisdictions, France and the USA. (New York: Routledge, 2006): 321.

69 The 1997 'People's Constitution' reinstated the mixed electoral system, where 400 MPs were elected via the first-past-the-post system and another 100 via the party list system. This change drove small parties out of politics - leaving only the two biggest ones, Thaksin Shinawatra's Thai Rak Thai Party and its rival, Abhisit Vejjajiva's Democratic Party. As Thaksin's extensive control had escalated into abuse of power during his mandate as prime minister between 2001-2006, the 2007 constitution reinstated the block vote system and divided the national party list into eight regional lists.

70 Section 27, Thai Constitution

71 Section 5, Thai Constitution

72 Section 28, Thai Constitution

73 Section 32, Thai Constitution

74 Section 37, Thai Constitution

75 Section 45, Thai Constitution

76 Section 64, Thai Constitution

77 Section 63, Thai Constitution

78 Section 63, Thai Constitution

79 Section 40, Paragraph 1, Thai Constitution

80 Section 40, Paragraph 2, Thai Constitution

81 Section 44, Thai Constitution

82 Part 8, Section 49 and 50, Thai Constitution

83 Sections 51, 52, 53, 54, 55, Thai Constitution

84 Sections 56, 57, Thai Constitution

85 Section 66, Thai Constitution

86 Section 66, Thai Constitution

87 Section 67, Thai Constitution

88 Part 4, Thai Constitution

89 Phan, Hao Duy. op. cit. p. 59

90 Connors, M. 'Ambivalent about Human Rights: Thai Democracy', in Thomas W.D. Davis and Brian Galligan (eds). Human Rights in Asia. (Glos, UK: Edward Elgar, 2011): 105

91 See Muntabhorn, Vitit. 'Human Rights in Thailand', in Randall Peerenboom et. al. (eds). Human Rights in Asia: A Comparative Case Study of Twelve Legal Jurisdictions, France and the USA. (New York: Routledge, 2006): 329-331.

92 https://www.hrw.org/world-report/2015/country-chapters/thailand

93 Ibid.

94 Connors, M. 'Ambivalent about Human Rights: Thai Democracy', in Thomas W.D. Davis and Brian Galligan (eds). Human Rights in Asia. (Glos, UK: Edward Elgar, 2011): 105,106

95 Phan, Hao Duy. op. cit. p. 54

96 'The right of the people to be secure in their persons, houses, papers, and effects against unreasonable searches and seizures of whatever nature and for any purpose shall be inviolable, and no search warrant or warrant of arrest shall issue except upon probable cause to be determined personally by the judge after examination under oath or affirmation of the complainant and the witnesses he may produce, and particularly describing the place to be searched and the persons or things to be seized'. Section 2, Article III, The Philippines Constitution. 97 Section 12, Article III, The Philippines Constitution

98 Section 16, Article III, The Philippines Constitution

99 Section 11, Article III, The Philippines Constitution

100 Section 4, Article III, The Philippines Constitution

101 Section 5, Article III, The Philippines Constitution

102 Section 18, The Philippines Constitution

103 Section 12, Article III, The Philippines Constitution

104 Section 11, Article II, The Philippines Constitution

105 Section 7, Article II, The Philippines Constitution

106 Section 15, Article II, The Philippines Constitution

107 Section 16, Article II, The Philippines Constitution

108 Section 17, Article II, The Philippines Constitution

109 Section 22, Article II, The Philippines Constitution

110 Ford, Michael, 'International Networks and Human Rights in Indonesia', in Thomas W.D. Davis and Brian Galligan (eds). Human Rights in Asia. (Glos, UK: Edward Elgar, 2011): 62

111 Section 2, Article II, The Philippines Constitution

112 Ford, Michael, 'International Networks and Human Rights in Indonesia', in Thomas W.D. Davis and Brian Galligan (eds). Human Rights in Asia. (Glos, UK: Edward Elgar, 2011): 63

113 Pangalangan, R.C., 'The Philippines: The Persistence of Rights Discourse vis-à-vis Substantial Social Claims, in in Randall Peerenboom et. al. (eds). Human Rights in Asia: A Comparative Case Study of Twelve Legal Jurisdictions, France and the USA. (New York: Routledge, 2006): 359

114 Phan, Hao Duy. op. cit., p. 56

115 Pangalangan, R.C., op. cit., p. 360

116 Pangalangan, R.C., op. cit., p. 355

117 Ford, Michael, 'International Networks and Human Rights in Indonesia', in Thomas W.D. Davis and Brian Galligan (eds). Human Rights in Asia. (Glos, UK: Edward Elgar, 2011): 63

118 Pangalangan, R.C. op. cit., p. 364.

119 The Human Rights Watch, for example, recently reported that the Philippine military has repeatedly stood aside while paramilitary forces have attacked indigenous villages and schools. See: Human Rights Watch, Philippines: Paramilitaries Attack Tribal Villages, Schools, Report. 23 September 2015. https:/ /www.hrw.org/news/2015/09/23/philippines-paramilitaries-attack-tribal-villages-schools

120 Human Rights Watch, "No Justice Just Adds to the Pain" Killings, Disappearances, and Impunity in the Philippines, Report. 18 July 2011. Available at https://www.hrw.org/report/2011/07/18/no-justice-just-adds-pain/killings-disappearances-and-impunityphilippines, accessed online 10 January 2018

121 Thomson, M. R. 'Duterte's illiberal democracy'. East Asia Forum. 7 August $2017 . \quad$ Available at http:/ / www.eastasiaforum.org/2017/08/07/80706/, accessed online 10 January 2018 
122 Ford, Michael, op. cit., p. 66

123 Phan, Hao Duy. op. cit., p. 56.

124 Juwana, I. op. cit., p. 366

125 Muntarbhorn, V. op. cit., p. 320

126 Connors, M. 'Ambivalent about Human Rights: Thai Democracy', in Thomas W.D. Davis and Brian Galligan (eds). Human Rights in Asia. (Glos, UK: Edward Elgar, 2011): 105-115

127 Ibid.

128 Thai jurists actively collaborated with coup regimes to write law and accept the legal status of a coup regimes to write law and accept the legal statues of a coup government, a pattern that started in 1947 and has persisted since, most recently in 2007.

129 The lack of resources and the major ideological splits regarding internal conflicts, for example the Mindanao and the Moro conflicts, are major challenges. Moreover, in Thailand, there is little progress due to problems in finding a workable definition of human rights for the country. Pangalangan, op. cit., p. 360.

130 Pangalangan, R.C., op. cit., p. 62

131 Mohammad, M., op. cit., p. 245.

132 Ibid., p. 243.

133 Human Rights Council, Report of the Special Rapporteur on the situation of human rights in the Democratic People's Republic of Korea, Marzuki Darusman*, A/HRC/28/71, 18 March 2015 